\title{
Influence of phthalates on glucose homeostasis and atherosclerosis in hyperlipidemic mice
}

Wei Zhou ${ }^{1,2}$, Mei-Hua Chen ${ }^{1}$ and Weibin SHI ${ }^{*}$

\begin{abstract}
Background: Phthalates are widely used as plasticizer and are considered as a typical endocrine-disrupting chemical. Epidemiological studies have associated serum or urinary phthalate metabolites with the prevalence of type 2 diabetes or related phenotypes. However, direct evidence supporting a causal role for exposure to phthalates in type 2 diabetes is lacking.

Methods: To determine the potential influence of phthalates on glucose homeostasis and atherosclerosis, female apolipoprotein E-deficient $\left(\right.$ Apoe $^{-/-}$) mice were started at 6 weeks of age on a Western diet together with or without Bis-(2-ethylhexyl) phthalate. Phthalate was administered in drinking water at a daily dosage of $100 \mathrm{mg} / \mathrm{kg}$. We examined glucose and insulin tolerance, plasma glucose and triglyceride levels, body weight, and atherosclerotic lesions in the aortic root.

Results: Two weeks after treatment, phthalate-exposed mice had significantly higher fasting blood glucose level $(97.9 \pm 2.1$ vs. $84.3 \pm 5.3 \mathrm{mg} / \mathrm{dl}, P=0.034)$ and exhibited a trend of increased glucose intolerance compared to control mice. Insulin tolerance test on non-fasted mice 3 weeks after treatment revealed that phthalate had little influence on insulin sensitivity though phthalate-treated mice had a higher glucose concentration (159.2 \pm 6.0 vs. $145.2 \pm 3.6 \mathrm{mg} / \mathrm{dl} ; P=0.086)$. On the Western diet, Apoe $^{-/-}$mice showed a time-dependent rise in fasting plasma glucose and triglyceride levels. However, no significant differences were observed between phthalate-treated and control mice in either phenotype after 4, 8, and 12 weeks of phthalate exposure. Neither body weight nor atherosclerotic lesions of Apoe $^{-/-}$mice was affected.
\end{abstract}

Conclusion: This study indicates that exposure to phthalates gives rise to a brief interference of glucose homeostasis but has little impact on the development of type 2 diabetes and atherosclerosis in $\mathrm{Apoe}^{-/-}$mice.

Keywords: Phthalates, Type 2 diabetes, Atherosclerosis, Dyslipidemia, Mice

\section{Background}

Phthalates are one class of the most manufactured industrial chemicals worldwide and have been used as plasticizers to produce plastics. Due to noncovalent binding with plastics, phthalates can readily leach into foods and drinks from plastic containers. Phthalates are also present in products used for medical care and in personal cosmetics. Phthalate exposure levels for the general public are in the range of $1-10 \mu \mathrm{g} / \mathrm{kg} /$ day [1]. More than $75 \%$ of the population in the United States

\footnotetext{
* Correspondence: ws4v@virginia.edu

'Departments of Radiology \& Medical Imaging and of Biochemistry \& Molecular Genetics, University of Virginia, PO Box 801339, 266 Snyder Bldg, 480 Ray C Hunt Drive, Charlottesville, VA 22908, USA

Full list of author information is available at the end of the article
}

has had measurable levels of phthalate metabolites in the circulation or urine $[2,3]$.

Recent epidemiological studies indicate that exposure to phthalates is associated with increased waist circumference, insulin resistance, and even diabetes. In crosssectional studies, concentrations of urinary phthalate metabolites were found to be associated with increased waist circumference or insulin resistance in adult American males [4], certain age groups of females [5], selfreported diabetes among Mexican and American women [6,7], and Korean elderly [8]. Recent studies of Swedish elderly and American women show that serum or urinary levels of phthalate metabolites were associated with an increased prevalence of type 2 diabetes $[9,10]$. However, direct evidence supporting a causal role is scarce

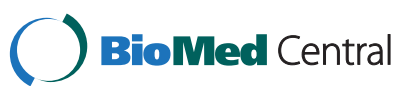

(c) 2015 Zhou et al.; licensee BioMed Central. This is an Open Access article distributed under the terms of the Creative Commons Attribution License (http://creativecommons.org/licenses/by/4.0), which permits unrestricted use, distribution, and reproduction in any medium, provided the original work is properly credited. The Creative Commons Public Domain Dedication waiver (http://creativecommons.org/publicdomain/zero/1.0/) applies to the data made available in this article unless otherwise stated. 
and even conflicting. For example, some studies showed that perinatal or adult exposure to phthalates lead to elevated blood glucose, reduced serum insulin, impaired glucose tolerance and insulin secretion in rodents [11-14] while others found the opposite results [15] or no effect at all [16]. Moreover, because the animals used in the studies did not develop type 2 diabetes, a causal link to the disease is still hypothetical.

Apolipoprotein E-deficient (Apoe ${ }^{-/-}$) mice is a commonly used animal model of atherosclerosis, which develops all phases of atherosclerotic lesions, progressing from the early fatty streak stage to the advanced stage with a fibrous cap and necrotic lipid core.[17] These mice also display the typical features of dyslipidemia observed in humans, including elevations in LDL cholesterol and triglyceride levels and reductions in HDL cholesterol levels.[18,19] We have found that Apoe $^{-/-}$ mice on the C57BL/6 genetic background develop significant hyperglycemia and type 2 diabetes when fed a Western diet [20]. In this study, we examined the influences of phthalates on the development of type 2 diabetes and atherosclerosis in the $\mathrm{Apoe}^{-/-}$mice.

\section{Methods}

\section{Animals}

$\mathrm{Apoe}^{-/-}$mice, which were on the C57BL/6 genetic background, were generated from breeding pairs purchased from the Jackson Laboratory, Bar Harbor, ME. At 6 weeks of age, female mice were switched onto a Western diet containing $21 \%$ fat, $0.15 \%$ cholesterol, $34.1 \%$ sucrose, $19.5 \%$ casein, and 15\% starch (TD88137, Harlan Laboratories) and maintained on the diet for 12 weeks. Female mice were chosen because they are more susceptible to atherosclerosis than male counterparts [21] and also they were used in our previous studies [22-25]. One group of mice received bis-(2-ethylhexyl) phthalate (Sigma) during Western diet consumption, and the control group received no phthalate. The phthalates were administered in drinking water at a daily dosage of $100 \mathrm{mg} / \mathrm{kg}$ of body weight for each mouse, as reported [26]. This dose has been shown to be effective in inducing estrogenic effects in mice [26]. All procedures were carried out in accordance with current National Institutes of Health guidelines and approved by the Institutional Animal Care and Use Committee.

\section{Glucose tolerance test (GTT) and insulin tolerance test (ITT)}

GTT and ITT were performed after 2 and 3 weeks of phthalate exposure, respectively, and GTT was also performed after 11 weeks of phthalate exposure. For GTT, mice were fasted overnight and then subjected to an intraperitoneal injection of glucose $(1 \mathrm{~g} / \mathrm{kg})$. Whole blood glucose was assessed with a glucometer using blood squeezed from cut tail tips immediately before and at 10 , $20,30,60,90$, and $120 \mathrm{~min}$ after the injection of glucose. ITT was performed on non-fasted mice by an intraperitoneal injection of insulin $(0.75 \mathrm{U} / \mathrm{kg})$. Blood glucose was measured immediately before and at $15,30,45$, and 60 min after insulin injection.

\section{Measurements of plasma glucose and triglyceride}

Mice were fasted overnight before blood was collected from the retro-orbital venous plexus by inserting a microhematocrit capillary with the animals under isoflurane anesthesia. Ethylenediaminetetraacetic acid (EDTA) was used as an anti-coagulant. Blood samples were centrifuged for $5 \mathrm{~min}$ at $12,000 \mathrm{~g}$ at $4^{\circ} \mathrm{C}$, and the resulting plasma was stored at $-80^{\circ} \mathrm{C}$ before assay. Plasma glucose was measured with a Sigma glucose (HK) assay kit, [27] and plasma triglyceride was measured with a Thermo DMA triglyceride kit [28].

\section{Atherosclerotic lesion analysis}

Atherosclerotic lesions in the aortic root were measured as previously reported [29,30]. Briefly, at the end of the experiments, the vasculature of mice was perfused with $4 \%$ paraformaldehyde for approximately $5 \mathrm{~min}$ through the heart. The aortic root and adjacent heart were excised and sectioned in $10-\mu \mathrm{m}$ thickness on a cryostat. Cryosections were stained with oil red $\mathrm{O}$ and hematoxylin and counterstained with fast green. Atherosclerotic lesion areas were measured with a Zeiss PrimoStar microscope connected with an Axiocam camera. The lesion areas of five sections with the largest readings were averaged for each mouse, and this average was used for statistical analysis.

\section{Statistical analysis}

Values were expressed as means $\pm \mathrm{SE}$, with $n$ indicating the number of mice. AVOVA or Student's $t$ test were used for determining statistical significance between groups. Differences were considered statistically significant at $P<0.05$.

\section{Results}

\section{Effect on body weight}

The body weight of $\mathrm{Apoe}^{-/-}$mice was measured at 2 and 12 weeks after the initiation of phthalate exposure. As shown in Figure 1, the body weight of the mice treated with phthalate was not significantly different from that of the control mice at both the 2 week (17.7 \pm 0.5 vs. $17.4 \pm 0.6 \mathrm{~g})$ and 12 week time points $(20.6 \pm 0.5$ vs. $22.1 \pm 0.6 \mathrm{~g})$.

\section{Early effect on glucose homeostasis}

Glucose tolerance test (GTT) and insulin tolerance test (ITT) were performed on the mice that had been exposed to phthalate for 2 and 3 weeks, respectively. In 

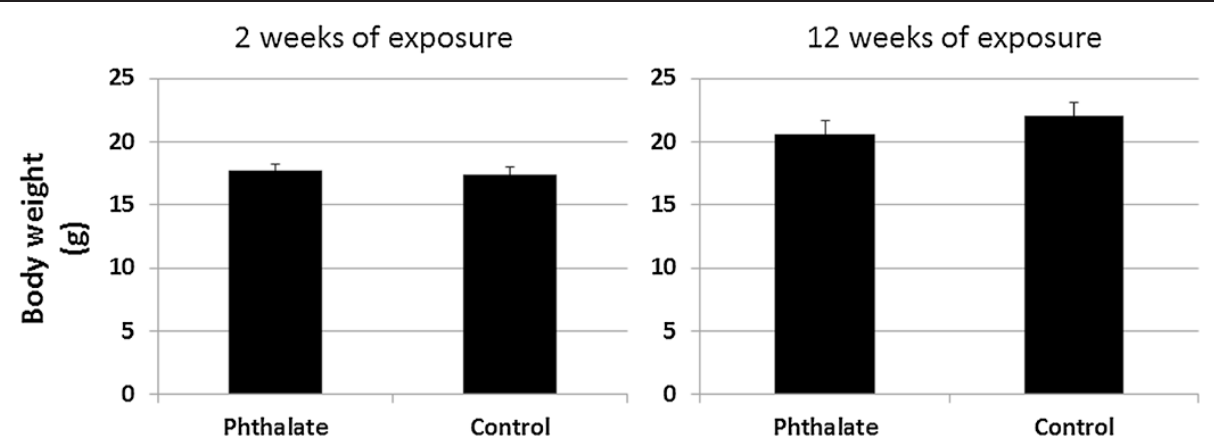

Figure 1 Body weight $(\mathrm{g})$ of female Apoe ${ }^{-/-}$mice at 2 and 12 weeks after the initiation of a Western diet plus phthalate. Control mice were fed with the high fat diet but were not treated with phthalate. Phthalate was administered in drinking water at a daily dosage of $100 \mathrm{mg} / \mathrm{kg}$ of body weight. Results are means \pm SE of 5 to 9 mice per group at each time point.

response to intraperitoneally injected glucose, blood glucose levels quickly rose to the peak at the $10^{\text {th }} \mathrm{min}$ for the phthalate-treated mice and at the $20^{\text {th }} \mathrm{min}$ for the control mice (Figure 2). After the peak, glucose levels fell gradually. Compared with control mice, phthalatetreated mice exhibited a trend of worsened glucose intolerance: At the $10^{\text {th }} \mathrm{min}$, the phthalate group had a blood glucose level of $270.4 \pm 19.6 \mathrm{mg} / \mathrm{dl}$, as compared to a level of $226.6 \pm 12.3 \mathrm{mg} / \mathrm{dl}$ in control mice $(P=$ $0.10)$. At the $30^{\text {th }} \mathrm{min}$, phthalate-treated mice had a blood glucose level of $235.6 \pm 20.4 \mathrm{mg} / \mathrm{dl}$ compared to $190.4 \pm 17.2 \mathrm{mg} / \mathrm{dl}$ of control mice $(P=0.13)$. In addition, the basal fasting blood glucose level (at $0 \mathrm{~min}$ ) was significantly higher in the phthalate-treated mice than in the control mice $(97.9 \pm 2.1$ vs. $84.3 \pm 5.3 \mathrm{mg} / \mathrm{dl}$, $P=0.034)$. GTT was also performed after mice were exposed to phthalates for 11 weeks, but no significant differences were observed between the two groups (data not shown).

ITT was performed on non-fasted mice. In response to insulin, both group of mice showed a deep and long- lasting fall in blood glucose levels. However, the basal non-fasting blood glucose level (at $0 \mathrm{~min}$ ) was higher in phthalate-exposed mice than in control mice (159.2 \pm 6.0 vs. $145.2 \pm 3.6 \mathrm{mg} / \mathrm{dl})$, although the difference did not statistical significance $(P=0.086)$.

\section{Long-term effect on fasting glucose and triglyceride}

Fasting plasma glucose and triglyceride were measured for phthalet-exposed and control mice before and after 4,8 and 12 weeks of phthalate exposure. Both groups of mice showed a time-dependent rise in both fasting glucose (Figure 3) and triglyceride levels (Figure 4) during the 12 weeks' feeding period on the Western diet. Fasting plasma glucose level was $109.3 \pm 8.8 \mathrm{mg} / \mathrm{dl}$ in phthalate-exposed mice and $116.2 \pm 6.7 \mathrm{mg} / \mathrm{dl}$ in control mice immediately before the initiation of the Western diet and rose to $279.0 \pm 11.8$ and $308.4 \pm 12.3 \mathrm{mg} / \mathrm{dl}$, respectively, at the end of the Western diet. Triglyceride levels rose from $48.0 \pm 8.6 \mathrm{mg} / \mathrm{dl}$ in phthalate-exposed mice and $43.4 \pm 2.2 \mathrm{mg} / \mathrm{dl}$ in control mice before the initiation of the Western diet to $63.6 \pm 8.7$ and $66.9 \pm$
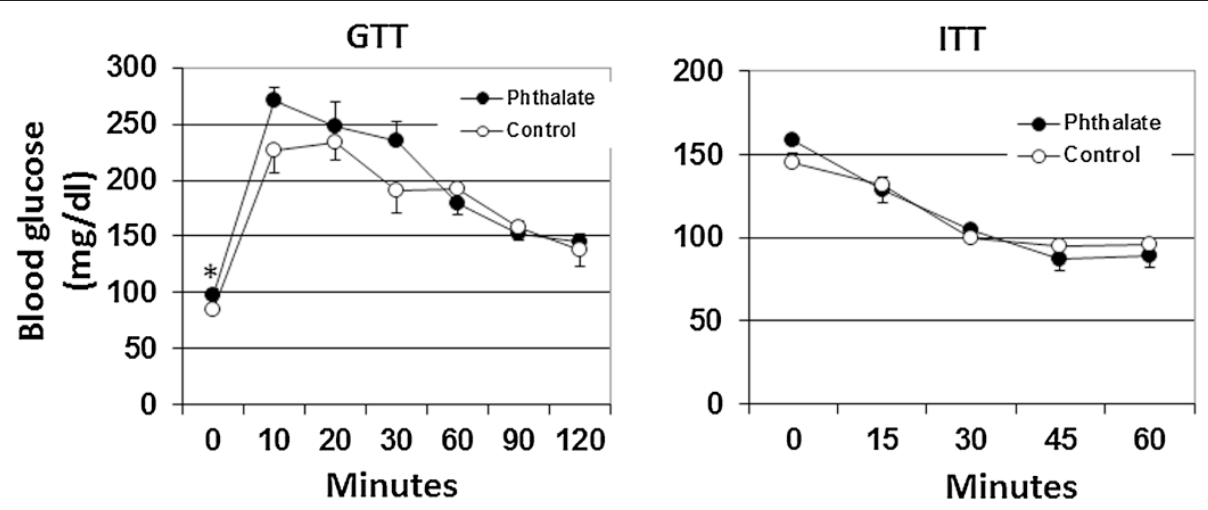

Figure 2 Glucose tolerance test (GTT) and insulin tolerance test (ITT) performed on the Apoe ${ }^{-/-}$mice after being exposed to phthalate for 2 and 3 weeks, respectively. For GTT, mice were fasted overnight and then subject to an intraperitoneal injection of glucose (1 g/kg). ITT was performed on non-fasted mice with an intraperitoneal injection of insulin $(0.75 \mathrm{U} / \mathrm{kg})$. Blood glucose concentrations were determined with a glucometer using blood taken from cut tail tips. Values are means \pm SE of 5 mice. ${ }^{*} P<0.05$ vs. control mice. 


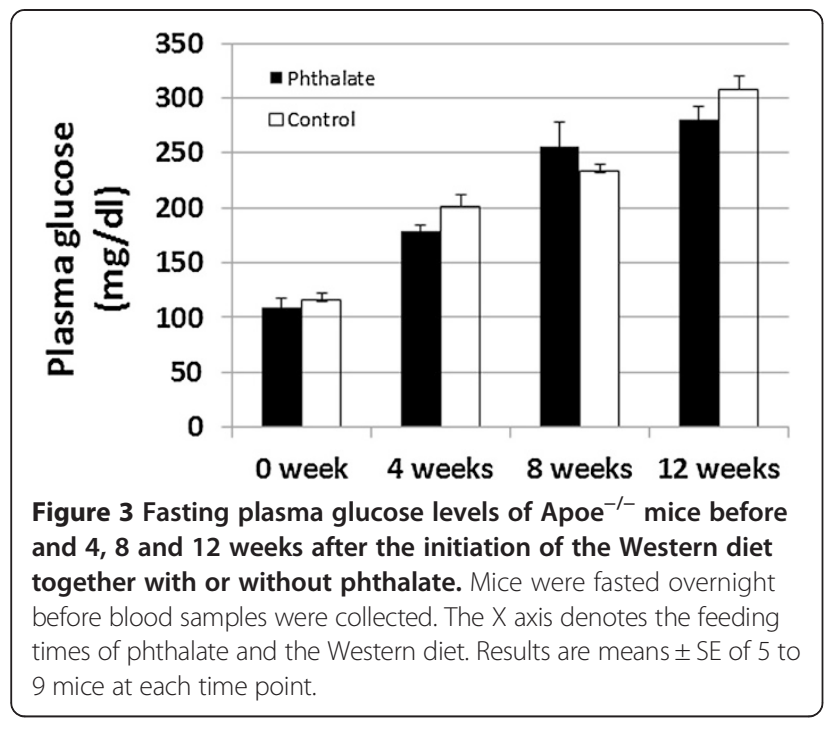

$5.2 \mathrm{mg} / \mathrm{dl}$, respectively, by the end of the Western diet. However, no significant differences were observed between the two groups in either fasting glucose or triglyceride $(P>0.05)$.

\section{Effect on advanced atherosclerotic lesion formation}

After 12 weeks of exposure to phthalate and the Western diet, $\mathrm{Apoe}^{-/-}$mice were euthanized for assessment of plaque formation in the aortic root. Both groups of mice developed advanced atherosclerotic lesions that contained cholesterol clefts and necrotic areas (Figure 5). The mice exposed to phthalate had an average aortic lesion area of $577,440 \pm 36,738 \mu^{2} /$ section, which was comparable to the lesion area of $568,459 \pm 47,044 \mu^{2} /$ section in control mice.

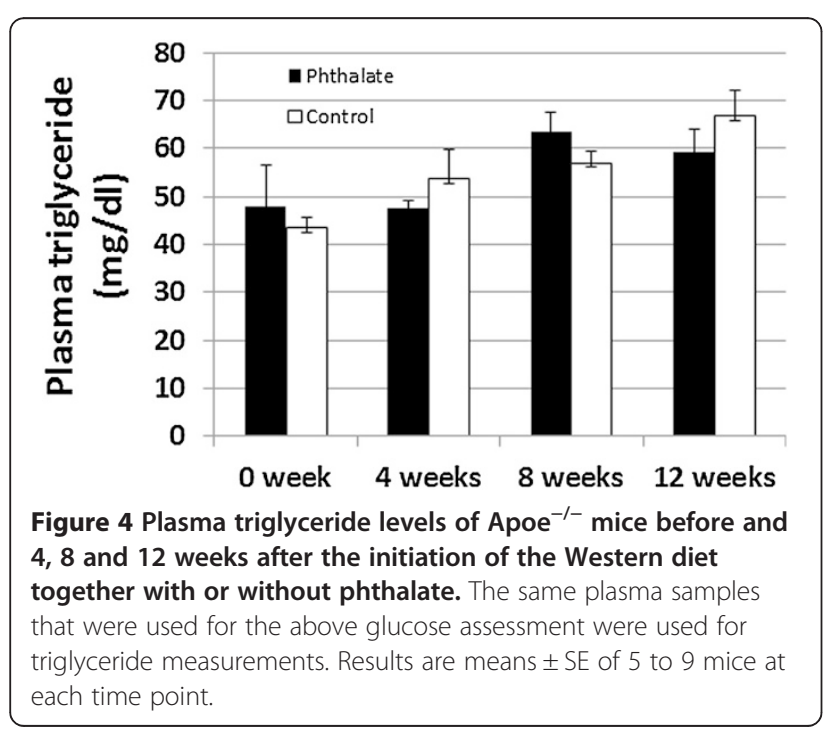

\section{Discussion}

High fat or nutrient diet is known to play an important part in the high prevalence of obesity, type 2 diabetes, and cardiovascular disease. Phthalates in plastic containers leach into foods and drinks. Thus, simultaneous intake of both high fat diet and phthalates is a daily reality. In this study, we used the Apoe ${ }^{-/-}$model of atherosclerosis to evaluate the influences of phthalates on the development of diet-induced type 2 diabetes and atherosclerosis. We demonstrated that phthalates only exerted temporary effects on glucose homeostasis and glucose tolerance in the early stage of exposure (2-3 weeks) and its longer term effects on body weight, type 2 diabetes, and atherosclerosis were not significant.

We previously found that $\mathrm{Apoe}^{-/-}$mice on the C57BL/6 genetic background develop significant hyperglycemia and type 2 diabetes when fed a Western diet $[31,22]$. Accordingly, in this study we observed a timedependent rise of fasting plasma glucose in the $\mathrm{Apoe}^{-/-}$ mice on the Western diet. By the $12^{\text {th }}$ week, Apoe $^{-/-}$ mice treated either with or without phthalates had a fasting glucose level surpassing $250 \mathrm{mg} / \mathrm{dl}$ (Figure 3). Diabetes is defined by fasting hyperglycemia. Fasting plasma glucose exceeding $250 \mathrm{mg} / \mathrm{dl}$ is considered diabetic for mice [32]. Clearly, these mice had developed type 2 diabetes by the $12^{\text {th }}$ week on the Western diet. One interesting finding in the present study was that mice treated with phthalates exhibited elevations in fasting and non-fasting glucose and impairments in glucose intolerance in the first 2 to 3 weeks of Western diet consumption, although the magnitudes of alterations were small. This finding is in agreement with previous observations from rats $[11,13]$. Phthalates have been shown to decrease serum insulin level [33] and interfere with insulin signal transduction in adipose tissue [13], both of which could lead to rises in blood glucose.

In this study, we found that a prolonged phthalate exposure did not affect fasting glucose of Apoe ${ }^{-/-}$mice fed the Western diet. This finding agrees with a recent observation made from wild-type C57BL/6 mice fed a high fat diet [16]. The reasons for the disappearance of the effect of phthalates on glucose homeostasis over time are clear. One explanation is that as phthalates induce cytochrome P-450 and other enzymes capable of metabolizing them [34], subsequently the accelerated degradation would weaken their effects. Another explanation is that as blood glucose levels are controlled by multiple factors, the small defect caused by phthalates could be compensated by other regulators over time.

Previous studies have shown that phthalates cause a significant reduction in plasma triglyceride levels in high fat-fed wild-type C57BL/6 mice [16] and F344 rats [15]. However, we did not find any changes in plasma triglyceride level of $\mathrm{Apoe}^{-/-}$mice treated with phthalates. 


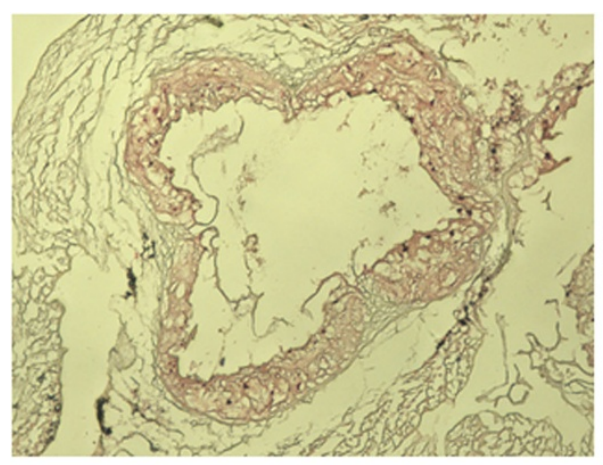

Phthalate

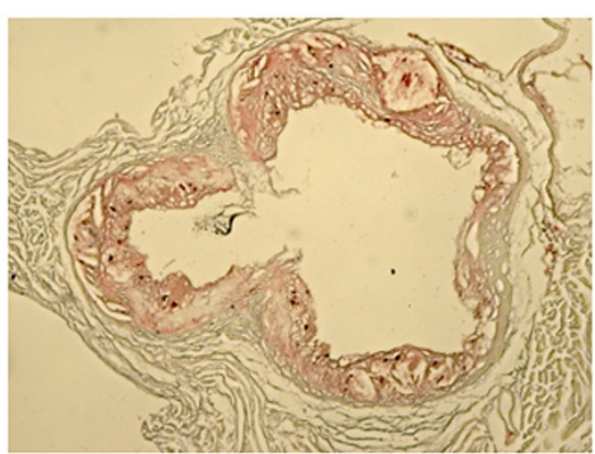

Control

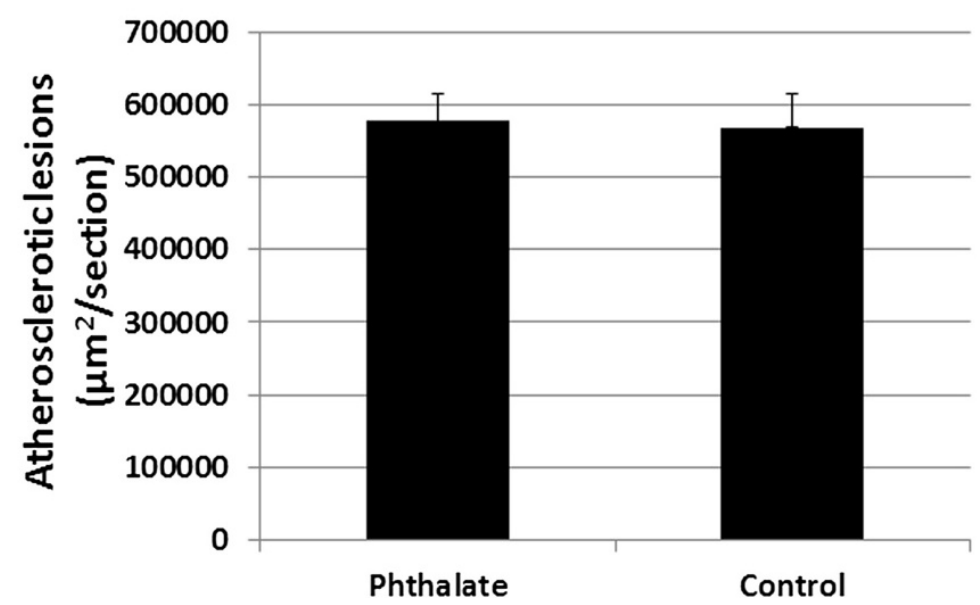

Figure 5 Atherosclerotic lesions in the aortic root of Apoe ${ }^{-1-}$ mice fed the Western diet together with or without phthalate. Upper panel: Representative light microscopic pictures of aortic lesions stained with oil red $\mathrm{O}$ and hematoxylin. Lower panel: Quantitative measurements of atherosclerotic lesions in the aortic root stained with oil-red $\mathrm{O}$. Values are mean \pm SE of 8 mice for each group.

One explanation for the discrepancy between this study and previous ones is the different dosages of phthalates: we used a much lower daily dosage $(100 \mathrm{mg} / \mathrm{kg})$ than the previous studies $(500 \sim 1000 \mathrm{mg} / \mathrm{kg})$. Another explanation is that the effect of phthalates on triglyceride might be more readily uncovered in the animals that have higher triglyceride levels $(100 \mathrm{mg} / \mathrm{dl}$ in wild-type mice compared to $\sim 50 \mathrm{mg} / \mathrm{dl}$ in the Apoe ${ }^{-/-}$mice).

A recent cross-sectional study of over 1016 Caucasians aged 70 found that serum levels of a phthalate metabolite were related to carotid artery plaques [9]. However, the association was not linear rather an inverted Ushape, which did not support a causal relationship. In this study, we directly tested the effect of phthalates on plaque formation in Apoe $^{-/-}$mice. The present finding did not show any significant effect on plague formation as mice treated with phthalates developed atherosclerotic lesions similar to those receiving no phthalates.

Epidemiological studies have suggested a role of phthalates in obesity, but the results from the human studies was inconsistent $[35,36,4,5,37,38]$. In this study, we found that phthalates had no influence on body weight of $\mathrm{Apoe}^{-/-}$ mice on the Western diet. In a recent study, Feige et al. [16] even found that the phthalate protected wild-type C57BL/6 mice from high fat diet-induced body weight increases. We and others previously found that female B6. Apoe $^{-/-}$mice had no increase in body weight on the Western diet $[22,31,39]$. Thus, there is a possibility that female B6.Apoe ${ }^{-/-}$mice are not an appropriate model for assessing the effect of phthalates on body weight.

The present study has several limitations. First, we only tested one single dosage that has been shown to be effective in altering blood glucose levels in rats $[11,13]$. As the magnitudes of exposure to phthalates vary greatly among the general population, a single dosage of exposure may not be able to reflect their real heath influences. Second, only female Apoe ${ }^{-1-}$ mice were included in the present study, while these mice do not develop obesity on a high fat diet. Third, there was a possibility that the effect of phthalates on diabetes and atherosclerosis was overwhelmed by Western diet feeding. Western diet consumption alone results in a gradual rise in fasting glucose and accelerates plaque formation; thus a small effect from phthalate might not show up. 
In summary, we have observed a brief influence of phthalate at a single higher dose on blood glucose and glucose tolerance of female Apoe ${ }^{-/-}$mice in the early phase of exposure. This influence disappeared within a few weeks. The overall impact of phthalate on the development of type 2 diabetes and atherosclerosis appears to be limited, although other doses that are more relevant to human situations need to be tested.

\section{Competing interests}

The authors declare that they have no competing interests.

\section{Authors' contributions}

WS designed the study; WZ, MHC, and WS performed experoments; WZ and WS analyzed, interpreted data and drafted the manuscript; and WZ, MHC and WS approved the version of the manuscript.

\section{Acknowledgments}

This study was supported by the National Institutes of Health grants DK097120 and HL112281.

\section{Author details}

'Departments of Radiology \& Medical Imaging and of Biochemistry \& Molecular Genetics, University of Virginia, PO Box 801339, 266 Snyder Bldg, 480 Ray C Hunt Drive, Charlottesville, VA 22908, USA. ${ }^{2}$ Department of Endocrinology of Jianghuai Hospital, Huaian, Jiangsu Province 223001, China.

Received: 3 December 2014 Accepted: 27 March 2015

Published online: 02 April 2015

\section{References}

1. Wittassek M, Koch HM, Angerer J, Bruning T. Assessing exposure to phthalates - the human biomonitoring approach. Mol Nutr Food Res. 2011;55(1):7-31.

2. Silva MJ, Barr DB, Reidy JA, Malek NA, Hodge CC, Caudill SP, et al. Urinary levels of seven phthalate metabolites in the U.S. population from the National Health and Nutrition Examination Survey (NHANES) 1999-2000. Environ Health Perspect. 2004;112(3):331-8.

3. Meeker JD, Calafat AM, Hauser R. Urinary phthalate metabolites and their biotransformation products: predictors and temporal variability among men and women. J Expo Sci Environ Epidemiol. 2012;22(4):376-85.

4. Stahlhut RW, van Wijngaarden E, Dye TD, Cook S, Swan SH. Concentrations of urinary phthalate metabolites are associated with increased waist circumference and insulin resistance in adult U.S. males. Environ Health Perspect. 2007;115(6):876-82.

5. Hatch EE, Nelson JW, Qureshi MM, Weinberg J, Moore LL, Singer M, et al. Association of urinary phthalate metabolite concentrations with body mass index and waist circumference: a cross-sectional study of NHANES data, 1999-2002. Environ Health. 2008;7:27.

6. Svensson K, Hernandez-Ramirez RU, Burguete-Garcia A, Cebrian ME, Calafat AM, Needham LL, et al. Phthalate exposure associated with self-reported diabetes among Mexican women. Environ Res. 2011;111(6):792-6.

7. James-Todd T, Stahlhut R, Meeker JD, Powell SG, Hauser R, Huang T, et al. Urinary Phthalate Metabolite Concentrations and Diabetes among Women in the National Health and Nutrition Examination Survey (NHANES) 2001-2008. Environ Health Perspect 2012; 120(9):1307-13.

8. Kim JH, Park HY, Bae S, Lim YH, Hong YC. Diethylhexyl phthalates is associated with insulin resistance via oxidative stress in the elderly: a panel study. PLOS ONE. 2013;8(8):e71392.

9. Lind PM, Zethelius B, Lind L. Circulating levels of phthalate metabolites are associated with prevalent diabetes in the elderly. Diabetes Care. 2012;35(7):1519-24.

10. Sun $\mathrm{Q}$, Cornelis MC, Townsend MK, Tobias DK, Eliassen AH, Franke AA, et al. Association of Urinary Concentrations of Bisphenol A and Phthalate Metabolites with Risk of Type 2 Diabetes: A Prospective Investigation in the Nurses' Health Study (NHS) and NHSII Cohorts. Environ Health Perspect. 2014;122(6):616-23
11. Martinelli Ml, Mocchiutti NO, Bernal CA. Dietary di(2-ethylhexyl)phthalateimpaired glucose metabolism in experimental animals. Hum Exp Toxicol. 2006;25(9):531-8.

12. Lin Y, Wei J, Li Y, Chen J, Zhou Z, Song L, et al. Developmental exposure to di(2-ethylhexyl) phthalate impairs endocrine pancreas and leads to longterm adverse effects on glucose homeostasis in the rat. Am J Physiol Endocrinol Metab. 2011;301(3):E527-38.

13. Rajesh P, Sathish S, Srinivasan C, Selvaraj J, Balasubramanian K. Phthalate is associated with insulin resistance in adipose tissue of male rat: role of antioxidant vitamins. J Cell Biochem. 2013;114(3):558-69.

14. Sun W, Ban JB, Zhang N, Zu YK, Sun WX. Perinatal exposure to di-(2-ethylhexyl)-phthalate leads to cognitive dysfunction and phospho-tau level increase in aged rats. Environ Toxicol. 2014;29(5):596-603.

15. Nakane F, Kunieda M, Shimizu S, Kobayashi Y, Akane H, Akie Y, et al. Twenty-six-week oral toxicity of diheptyl phthalate with special emphasis on its induction of liver proliferative lesions in male F344 rats. J Toxicol Sci. 2012;37(3):527-37.

16. Feige JN, Gerber A, Casals-Casas C, Yang Q, Winkler C, Bedu E, et al. The pollutant diethylhexyl phthalate regulates hepatic energy metabolism via species-specific PPARalpha-dependent mechanisms. Environ Health Perspect. 2010;118(2):234-41.

17. Nakashima Y, Plump AS, Raines EW, Breslow JL, Ross R. ApoE-deficient mice develop lesions of all phases of atherosclerosis throughout the arterial tree. Arterioscler Thromb. 1994;14(1):133-40.

18. Shi W, Wang NJ, Shih DM, Sun VZ, Wang X, Lusis AJ. Determinants of atherosclerosis susceptibility in the $\mathrm{C} 3 \mathrm{H}$ and $\mathrm{C} 57 \mathrm{BL} / 6$ mouse model: evidence for involvement of endothelial cells but not blood cells or cholesterol metabolism. Circ Res. 2000;86(10):1078-84.

19. Zhang SH, Reddick RL, Piedrahita JA, Maeda N. Spontaneous hypercholesterolemia and arterial lesions in mice lacking apolipoprotein E. Science. 1992;258(5081):468-71.

20. Su Z, Li Y, James JC, Matsumoto AH, Helm GA, Lusis AJ, et al. Genetic linkage of hyperglycemia, body weight and serum amyloid-P in an intercross between C57BL/6 and C3H apolipoprotein E-deficient mice. Hum Mol Genet. 2006;15(10):1650-8.

21. Paigen B, Holmes PA, Mitchell D, Albee D. Comparison of atherosclerotic lesions and HDL-lipid levels in male, female, and testosterone-treated female mice from strains C57BL/6, BALB/C, and C3H. Atherosclerosis. 1987;64(2-3):215-21

22. Li J, Wang Q, Chai W, Chen MH, Liu Z, Shi W. Hyperglycemia in apolipoprotein E-deficient mouse strains with different atherosclerosis susceptibility. Cardiovasc Diabetol. 2011;10(1):117.

23. Li J, Lu Z, Wang Q, Su Z, Bao Y, Shi W. Characterization of Bglu3, a mouse fasting glucose locus, and identification of Apcs as an underlying candidate gene. Physiol Genomics. 2012;44(6):345-51.

24. Manichaikul A, Wang Q, Shi YL, Zhang Z, Leitinger N, Shi W. Characterization of Ath29, a major mouse atherosclerosis susceptibility locus, and identification of Rcn2 as a novel regulator of cytokine expression. Am J Physiol Heart Circ Physiol. 2011;301(3):H1056-61.

25. Lu Z, Yuan Z, Miyoshi T, Wang Q, Su Z, Chang CC, et al. Identification of Soat1 as a quantitative trait locus gene on mouse chromosome 1 contributing to hyperlipidemia. PLOS ONE. 2011;6(10):e25344.

26. Ter Veld MG, Zawadzka E, Rietjens IM, Murk AJ. Estrogenicity of foodassociated estrogenic compounds in the fetuses of female transgenic mice upon oral and IP maternal exposure. Reprod Toxicol. 2009;27(2):133-9.

27. Zhang Z, Rowlan JS, Wang Q, Shi W. Genetic analysis of atherosclerosis and glucose homeostasis in an intercross between C57BL/6 and BALB/CJ apolipoprotein E-deficient mice. Circ Cardiovasc Genet. 2012;5(2):190-201.

28. Tian J, Pei H, James JC, Li Y, Matsumoto AH, Helm GA, et al. Circulating adhesion molecules in apoE-deficient mouse strains with different atherosclerosis susceptibility. Biochem Biophys Res Commun. 2005;329(3):1102-7.

29. Rowlan JS, Zhang Z, Wang Q, Fang Y, Shi W. New quantitative trait loci for carotid atherosclerosis identified in an intercross derived from apolipoprotein E-deficient mouse strains. Physiol Genomics. 2013;45(8):332-42.

30. Su Z, Li Y, James JC, McDuffie M, Matsumoto AH, Helm GA, et al. Quantitative trait locus analysis of atherosclerosis in an intercross between C57BL/6 and C3H mice carrying the mutant apolipoprotein E gene. Genetics. 2006;172(3):1799-807.

31. Zhang Y, Kundu B, Zhong M, Huang T, Li J, Chordia MD, et al. PET imaging detection of macrophages with a formyl peptide receptor antagonist. Nucl Med Biol. 2015;42(4):381-6. 
32. Clee SM, Attie AD. The genetic landscape of type 2 diabetes in mice. Endocr Rev. 2007;28(1):48-83.

33. Gayathri NS, Dhanya CR, Indu AR, Kurup PA. Changes in some hormones by low doses of di (2-ethyl hexyl) phthalate (DEHP), a commonly used plasticizer in PVC blood storage bags \& medical tubing. Indian J Med Res. 2004;119(4):139-44.

34. Lake BG, Rijcken WR, Gray TJ, Foster JR, Gangolli SD. Comparative studies of the hepatic effects of di- and mono-n-octyl phthalates, di-(2-ethylhexyl) phthalate and clofibrate in the rat. Acta Pharmacol Toxicol (Copenh). 1984;54(3):167-76.

35. Song Y, Hauser R, Hu FB, Franke A, Liu S, Sun Q. Urinary concentrations of bisphenol a and phthalate metabolites and weight change: a prospective investigation in US women. Int J Obes (Lond). 2014; 38(12):1532-7.

36. Trasande L, Attina TM, Sathyanarayana S, Spanier AJ, Blustein J. Race/ ethnicity-specific associations of urinary phthalates with childhood body mass in a nationally representative sample. Environ Health Perspect. 2013;121(4):501-6.

37. Lind PM, Roos V, Ronn M, Johansson L, Ahlstrom H, Kullberg J, et al. Serum concentrations of phthalate metabolites are related to abdominal fat distribution two years later in elderly women. Environ Health. 2012;11:21. 069X-11-21.

38. Wang H, Zhou Y, Tang C, He Y, Wu J, Chen Y, et al. Urinary phthalate metabolites are associated with body mass index and waist circumference in Chinese school children. PLoS ONE. 2013;8(2):e56800.

39. Teupser D, Pavlides S, Tan M, Gutierrez-Ramos JC, Kolbeck R, Breslow JL. Major reduction of atherosclerosis in fractalkine (CX3CL1)-deficient mice is at the brachiocephalic artery, not the aortic root. Proc Natl Acad Sci U S A. 2004;101(51):17795-800

\section{Submit your next manuscript to BioMed Central and take full advantage of:}

- Convenient online submission

- Thorough peer review

- No space constraints or color figure charges

- Immediate publication on acceptance

- Inclusion in PubMed, CAS, Scopus and Google Scholar

- Research which is freely available for redistribution 